\title{
Analisis Penerimaan User Terhadap Penerapan Sistem Reservasi Tiketing Bus Antar Kota Antar Provinsi dengan Menggunakan SMS
}

\author{
Oleh \\ : Rajib Ghaniy
}

\begin{abstract}
Abstrak
Pelayanan pemesanan tiket saat ini memiliki dua cara, konsumen dapat membeli tiket melalui pemesanan tiket secara konvensional yaitu pembeli datang langsung ke loket - loket pejualan tiket, yang kedua konsumen dapat memesan tiket secara online melalui fasilitas internet. Saat ini sebagian besar masyarakat masih memilih dengan memesan tiket secara konvensional, hal ini dikarenakan tidak semua masyarakat yang ingin memesan tiket mempunyai fasilitas internet dirumahnya atau tidak adanya waktu untuk meluangkan waktu untuk pergi ke warung internet (warnet) untuk memesan tiket secara online, belum lagi ada kemungkinan masih adanya masyarakat yang belum memahami internet itu sendiri. Akan tetapi pemesanan tiket secara online ini dapat diatasi dengan adanya pemesanan tiket menggunakan fasilitas jaringan telepon seluler, seperti dikutip dari Asosiasi Telepon Seluler Indonesia (ATSI) tercatat pengguna telepon seluler hingga juni 2010 diperkirakan mencapai 180 juta pelanggan atau $80 \%$ dari total penduduk Indonesia. Dengan adanya data tersebut memungkinkan terjadinya terobosan baru dalam pemesanan tiket dengan menggunakan fasilitas jaringan telepon seluler melalui sms (short message service) / pesan singkat. permasalahan yang sering muncul dalam proses reservasi tiket yang sedang berjalan saat ini yaitu menitik beratkan pada tingkat kenyamanan, keamanan penumpang dalam memesan tiket serta mencari nilai lebih yang mungkin diperoleh penumpang. Dengan perkembangan teknolgi informasi dengan didukung semakin banyaknya pengguna telepon seluler maka dapat diberikan jawaban dari permasalahan tersebut yakni dengan menciptakan terobosan baru yaitu proses pemesanan tiket dengan menggunakan teknologi sms (short message service), dengan tekniki sms gateway diharapkan proses pemberian informasi perjalanan, harga tiket serta proses pemesanan tiket dapat dilakukan dengan otomatis dan tanpa batas.
\end{abstract}

Kata Kunci : Tiket, Reservasi, SMS, SMS Gateway

\section{Pendahuluan}

\section{Latar Belakang Masalah}

Pelayanan pemesanan tiket saat ini memiliki dua cara, konsumen dapat membeli tiket melalui pemesanan tiket secara konvensional yaitu pembeli datang langsung ke loket - loket pejualan tiket, yang kedua konsumen dapat memesan tiket secara online melalui fasilitas internet. Saat ini sebagian besar masyarakat masih memilih dengan memesan tiket secara konvensional, hal ini dikarenakan tidak semua masyarakat yang ingin memesan tiket mempunyai fasilitas internet dirumahnya atau tidak adanya waktu untuk meluangkan waktu untuk pergi ke warung internet (warnet) untuk memesan tiket secara online, belum lagi ada kemungkinan masih adanya masyarakat yang belum memahami internet itu sendiri. Akan tetapi pemesanan tiket secara online ini dapat diatasi dengan adanya pemesanan tiket menggunakan fasilitas jaringan telepon seluler, seperti diungkapkan oleh Jafar M Sidik (2010, p.4) bahwa Asosiasi Telepon Seluler Indonesia (ATSI) mencatat pengguna telepon seluler hingga juni 2010 diperkirakan mencapai 180 juta pelanggan atau $80 \%$ dari total penduduk Indonesia. Dengan adanya data tersebut 
memungkinkan terjadinya terobosan baru dalam pemesanan tiket dengan menggunakan fasilitas jaringan telepon seluler melalui sms (short message service) / pesan singkat.

Dengan adanya pemesanan tiket melalui telepon seluler melalui sms ini diharapkan seluruh kalangan masyarakat dapat melakukan pemesanan tiket secara langsung dengan menggunakan telepon selular, selain itu segala kendala dalam pemesanan tiket konvensional seperti penumpukan antrian pembeli, pemalsuan tiket / penggunaan tiket ganda, bahkan pencurian tiket dapat ditekan, karena sistem reservasi tiket menggunakan sms ini akan menitik beratkan pada kenyamanan, keamanan, dan jangkauan yang mungkin dapat diperoleh oleh konsumen.

Proses reservasi tiket secara konvensional maupun online melalui internet masih menuai permasalahan Darajat Arianto (2010.p.8) mengatakan, masih saja ada tiket ganda dalam sebuah perjalanan kereta api. Padahal, dalam hal ini PT KA sudah melayani penjualan secara online. Artinya, setiap data pembeli atau pemesan tiket akan tertera secara online ke seluruh jaringan penjualan tiket, sehingga kemungkinan adanya tiket ganda dapat ditekan, akan tetapi tidak demikian keadaan yang terjadi, pemesanan tiket secara online pun masih terkendala dalam proses integrasi antar cabang penjualan tiket.

Dalam penelitian sebelumnya telah ada sistem pemesanan tiket menggunakan fasilitas telepon seluler, teknik yang dipakai yaitu dengan menggunakan fasilitas GPRS dan Barcode Data Matrix, dilihat dari segi teknologi kedua teknik tersebut bisa dikatakan lebih canggih akan tetapi kedua teknik tersebut mempunyai kelemahan yaitu, setiap konsumen yang ingin melakukan reservasi tiket haruslah mempunyai handphone canggih yang telah dilengkapi fasilitas GPRS dan mempunyai resolusi layar yang tinggi, yang menjadi permasalahan adalah tidak semua konsumen pemesan tiket mempunyai handphone yang canggih.

Dalam hal ini penulis akan mengkaji untuk mencari solusi alternatif sistem dengan memanfaatkan teknologi sistem informasi yaitu sistem pemesanan tiket dengan menggunakan fasilitas telepon seluler dengan menggunakan teknik sms gateway yang merupakan salah satu sistem informasi terkini yang mudah diterapkan. Diharapkan sistem pemesanan tiket ini bisa menjadi suatu solusi yang cukup andal dalam mengatasi permasalahan yang ada selama ini dalam proses reservasi tiket dan bisa dijangkau oleh semua kalangan.

\section{Permasalahan}

Jika diidentifikasikan dari latar belakang yang telah diungkapkan diatas maka problem statement yang diangkat dalam penelitian ini adalah belum adanya deskripsi mengenai sebuah sistem informasi pemesanan tiket bus antar kota antar propinsi yang memberikan kenyamanan, keamanan dan nilai tambah bagi penumpangnya.

Adapun dari problem statement tersebut maka rumusan masalah atau research question dari penelitian ini adalah bagaimana mendeskripsikan sistem reservasi tiket bus 
antar kota antar propinsi melalui sms dapat memberikan kenyamanan, keamanan, dan nilai tambah bagi penumpang.

\section{Maksud Penelitian}

Adapun maksud dari penelitian ini adalah terwujudnya rancangan sistem pemesanan tiket menggunakan teknik sms gateway yang dapat mendukung pemesanan tiket secara langsung melalui sms. dan mencoba memberikan solusi alternatif untuk berbagai permasalahan yang muncul dalam penjualan tiket yang dilakukan secara konvensional, baik itu masalah teknis seperti penumpukan antrian penumpang, maupun masalah non teknis seperti pemalsuan tiket.

\section{Landasan Teori}

\section{Short Message Service (SMS)}

a. Pengenalan Short Message Service (SMS)

SMS merupkan salah satu fitur pada GSM (Global Services for Mobile Communication) yang dikembangkan dan distandarisasi oleh ETSI (Eropean Telecommunications Standards Institute) untuk mengirim ataupun menerima pesan singkat yang berupa tulisan (teks) dengan menggunakan media komunikasi telepon seluler.

b. Layanan SMS

SMS terdiri dari dua layanan dasar yaitu :

1) Short Message Mobile Terminated (SMMT), yaitu kemampuan sistem GSM untuk menyampaikan pesan pendek yang dikirim dari service center (SC) ke Mobile Station (MS), dan menghasilkan informasi tentang pengiriman itu baik delivery report (laporan pengiriman) atau Status Report (status pengiriman) dengan mekanisme tertentu.

2) Short Message Mobile Oriented (SMMO), yaitu kemampuan dari sistem GSM untuk menyampaikan pesan pendek yang dikirimkan dari Mobile Station (MS) ke satu Short Message Entity (SME) melalui sebuah service centre (SC), dan menghasilkan informasi tentang pengiriman itu baik delivery report atau failure report.

c. Karakteristik SMS

Ada beberapa yang menjadi karakteristik SMS adalah sebagai berikut :

1) Satu pesan pasti sampai atau tidak sama sekali ke ponsel tujuan. Jika terjadi kegagalan sistem, time out, atau karena faktor lain yang menyebabkan pesan tidak dapat dikirim, akan diberikan informasi (report) yang menyatakan pesan gagal dikirimkan.

2) Jika ponsel yang dituju dalam keadaan tidak aktif maka SMS akan masuk ke antrian dengan status tertunda (pending) selama belum time out, jika sudah time out 
maka statusnya menjadi gagal (failed), pesan akan segera dikirimkan jika ponsel tujuan sudah aktif dengan status terkirim (delivered).

3) SMS berbasis teks menggunakan bandwith yang rendah.

\section{d. Prinsip Kerja SMS}

Adi purnomo (2007, p.5) menunjukan bahwa ketika pengguna mengirim pesan ke suatu nomer, SMS tersebut tidak akan langsung dikirimkan ke nomer tujuan, namun akan masuk terlebih dahulu ke SMS centre (SMSC) operator telepon yang digunakan oleh pengguna. SMS centre sendiri dapat diartikan sebagai sebuah server yang bertanggung jawab pada proses pengiriman SMS dalam suatu operator.

SMS yang dikirimkan dari suatu ponsel akan masuk dan disimpan kedalam SMSC ini, kemudian baru diteruskan ke nomer tujuan SMS tersebut. Apabila nomer yang dituju sedang mati (offline), SMSC ini akan menyimpan SMS tersebut untuk sementara waktu hingga nomer tujuan hidup kembali. Lamanya waktu penyimpanan SMS pada SMSC, sangat tergantung dari lamanya waktu yang telah ditetapkan oleh operator untuk menyimpan SMS tersebut. Kemudian nomer yang telah menerima SMS akan mengirimkan laporan ke SMSC yang menyatakan bahwa SMS telah diterima. Laporan tersebut kemudian akan diteruskan kembali ke nomer pengirim SMS, skema pengiriman pesan singkat dapat dilihat pada gambar 1 (Skema cara kerja sms).

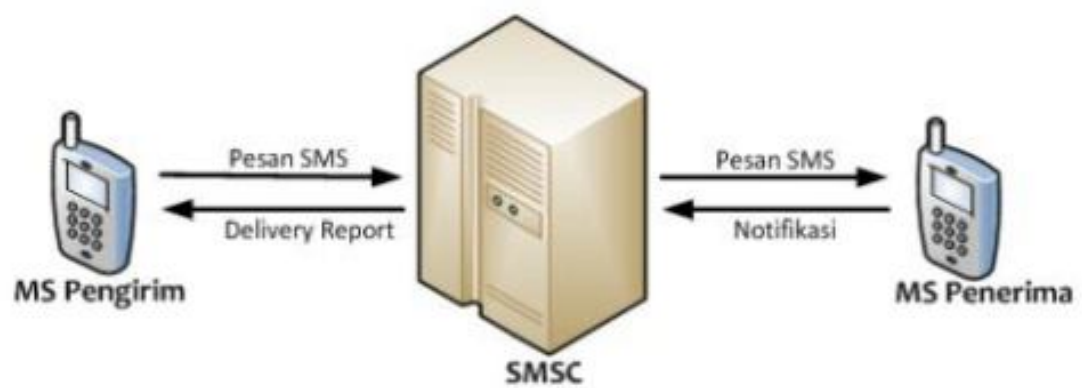

Gambar 1. Skema Cara Kerja SMS

\section{SMS Gateway}

1. Pengertian SMS Gateway

SMS gateway adalah suatu platform yang menyediakan mekanisme untuk menghantar dan menerima SMS dari peralatan mobile (HP, PDA phone, dan lain-lain) yang menggunakan keyword tertentu. SMS Gateway merupakan SMS interaktif yang memiliki komunikasi dua arah.

2. Mekanisme SMS Gateway

SMS Gateway menerima SMS dari user sesuai dengan format SMS (keyword) yang telah ditentukan sebelumnya, kemudian akan melakukan validasi data serta melakukan pemrosesan terhadap data-data yang telah dikirimkan oleh user melalui SMS Gateway, Kemudian selanjutnya sistem akan mengirimkan informasi hasil dari 
pemrosesan data tersebut dalam bentuk format pesan singkat SMS yang berdasarkan keyword sesuai dengan permintaan user tersebut

3. AT Command

AT Command (Access Terminal Command) merupakan perintah-perintah yang digunakan dalam komunikasi telepon dengan serial port pada komputer. Adi purnomo (2007, p.9) dalam bukunya mengatakan dengan perintah AT Command ini komputer dapat berinteraksi dengan telepon seluler, misalnya seperti melihat vendor dari telepon seluler yang digunakan, mengecek koneksi telepon seluler dengan komputer, membaca pesan yang terdapat pada SIM card, mengirim pesan, mendeteksi pesan baru yang masuk secara otomatis, menghapus pesan dan sebagainya.

4. GSM Cable Data

GSM cable data adalah perangkat keras atau rangkaian kabel data dari ponsel GSM yang berfungsi untuk menghubungkan antara ponsel dengan komputer agar dapat berkomunikasi melalui port USB. Kabel data yang akan dipakai harus disesuaikan dengan ponsel yang digunakan agar dapat terjalin komunikasi. Kabel data biasanya dimanfaatkan sebagai perantara interaksi antara ponsel ke komputer seperti halnya modem untuk akses internet, dengan ini pertukaran data antara ponsel dengan komputer lebih cepat dan mudah.

\section{Desain Penelitian}

Model pengembangan penelitian ini menggunakan model prosedural yang bersifat deskriptif berisikan langkah - langkah yang harus diikuti untuk menghasilkan produk, berikut adalah gambaran umum dari model prosedural yang dipakai di ambil dari model prototipe yang telah melalui modifikasi.

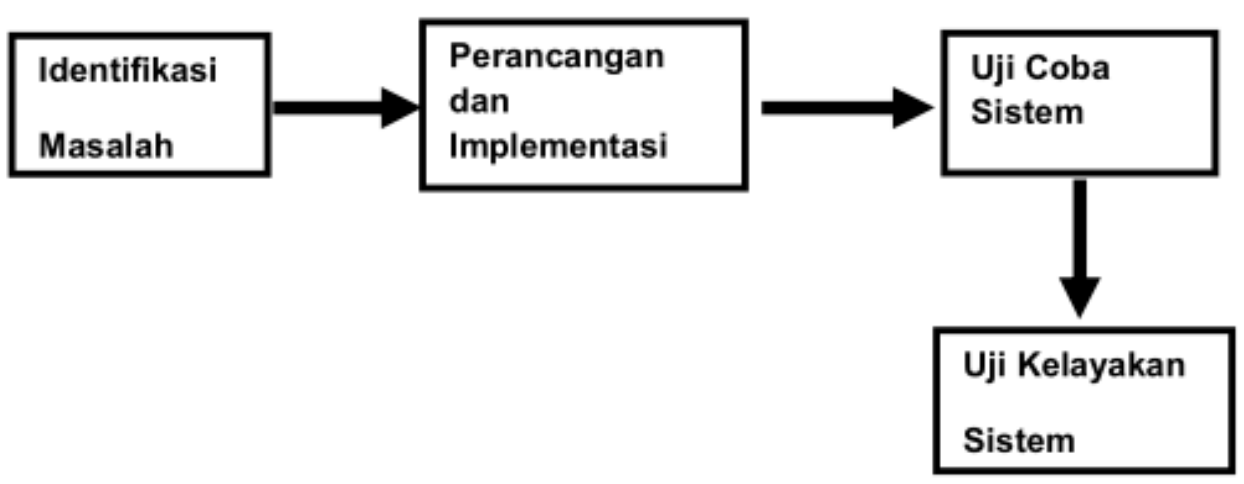

Gambar 2. Desain Penelitian

\section{Variabel Penelitian}

Nilai $\mathrm{X}$ merupakan nilai variabel mengukur trend dari sistem, dimana atribut yang dinilai adalah efektifitas, keamanan, kualitas, waktu, dan efisiensi dari sistem. Nilai $Y$ 
merupakan nilai variabel untuk mengetahui layanan sistem, dimana atribut yang dinilai adalah Tangibles (wujud), Reliability (keandalan), Emphaty (empati)

\section{Instrumen Penelitian}

Adapun instrumen dalam penelitian ini untuk sistem informasi penjualan tiket bus dengan menggunakan dengan menggunakan sms sebagai berikut:

Tabel 1. Instrumen Penelitian

\begin{tabular}{|c|c|c|c|}
\hline Variabel & Dimensi & Indikator & $\begin{array}{l}\text { Butir } \\
\text { Pernyataan }\end{array}$ \\
\hline \multirow{5}{*}{$\begin{array}{l}X: \text { Trend } \\
\text { dari sistem }\end{array}$} & Efektivitas & $\begin{array}{l}\text { 1. Penilaian output } \\
\text { 2. Fungsi output }\end{array}$ & $\begin{array}{l}1 \\
2\end{array}$ \\
\hline & Keamanan & $\begin{array}{l}\text { 1. Keamanan system } \\
\text { 2. Solusi keamanan }\end{array}$ & $\begin{array}{l}3 \\
4\end{array}$ \\
\hline & Kualitas & $\begin{array}{l}\text { 1. Kebutuhan } \\
\text { 2. Harapan }\end{array}$ & $\begin{array}{l}5 \\
6\end{array}$ \\
\hline & Waktu & Respon sistem & 7,8 \\
\hline & Efisiensi & Resolve problem & 9 \\
\hline \multirow{3}{*}{$\begin{array}{l}\text { Y : Layanan } \\
\text { Sistem }\end{array}$} & $\begin{array}{l}\text { Tangibles } \\
\text { (wujud) }\end{array}$ & Fasilitas & 10 \\
\hline & $\begin{array}{l}\text { Reliability } \\
\text { (keandalan) }\end{array}$ & $\begin{array}{l}\text { 1. Akurat } \\
\text { 2. Handal }\end{array}$ & $\begin{array}{l}11 \\
12\end{array}$ \\
\hline & $\begin{array}{l}\text { Emphaty } \\
\text { (empati) }\end{array}$ & $\begin{array}{l}\text { 1. Akses } \\
\text { 2. Komunikasi } \\
\text { 3. Pemahaman pada pemakai }\end{array}$ & $\begin{array}{l}13 \\
14 \\
15\end{array}$ \\
\hline
\end{tabular}

\section{Metode Analisa Data}

Teknik yang digunakan dalam menganalisa data berdasarkan jenis data yang dipakai yaitu penghitungan data akan diungkapkan dengan data kuantitatif, dengan menggunakan angka indeks korelasi "r" product moment di mana $\mathrm{N}$ kurang dari 30 , dengan mendasarkan diri pada skor aslinya atau angka kasarnya.

Rumus yang akan digunakan :

$$
\begin{aligned}
& r_{X Y}=\frac{N \sum X Y-\left(\sum X\right)\left(\sum Y\right)}{\sqrt{\left[N \sum X^{2}-\left(\sum X\right)^{2}\right]\left[N \sum Y^{2}-\left(\sum Y\right)^{2}\right]}} \\
& r_{X Y}=\text { Angka Indeks Korelasi "r" Froduct Moment } \\
& N=\text { Number of Cases } \\
& \sum X Y=\text { Jamiah hasil perkalian Skor } X \text { dan skor } Y \\
& \sum X=\text { Jumlah seluruh skar } X
\end{aligned}
$$


$\sum Y=$ Jumlah Seluruh Skor $Y$

Metode ini digunakan untuk mencari korelasi antara media informasi terhadap kebutuhan informasi masyarakat, kemudian dicocokan dengan tabel konservatif berikut :

Tabel 2. Tabel Konservatif

\begin{tabular}{|c|l|}
\hline $\begin{array}{c}\text { Besarnya "r" Product } \\
\text { Moment }\left(\mathbf{r}_{\mathbf{x y}}\right)\end{array}$ & \multicolumn{1}{|c|}{ Interpretasi } \\
\hline 0,00 s.d 0,20 & Antara variabel $\mathrm{X}$ dan variabel $\mathrm{Y}$ tidak ada korelasi \\
\hline 0,20 s.d 0,40 & $\begin{array}{l}\text { Antara variabel } \mathrm{X} \text { dan variabel } \mathrm{Y} \text { terdapat korelasi } \\
\text { lemah atau rendah }\end{array}$ \\
\hline 0,40 s.d 0,70 & $\begin{array}{l}\text { Antara variabel } \mathrm{X} \text { dan variabel } \mathrm{Y} \text { terdapat korelasi } \\
\text { sedang atau cukupan }\end{array}$ \\
\hline 0,70 s.d 0,90 & $\begin{array}{l}\text { Antara variabel } \mathrm{X} \text { dan variabel } \mathrm{Y} \text { terdapat korelasi } \\
\text { kuat atau tinggi }\end{array}$ \\
\hline 0,90 s.d 1,00 & $\begin{array}{l}\text { Antara variabel } \mathrm{X} \text { dan variabel } \mathrm{Y} \text { terdapat korelasi } \\
\text { sangat kuat atau sangat tinggi }\end{array}$ \\
\hline
\end{tabular}

Nilai yang didapat kemudian dikorelasikan dengan tabel konservatif diatas, dengan demikian kita dapat mengetahui sejauh mana sistem yang dibuat dapat menjawab tujuan dari penelitian ini.

\section{Permulaan Sistem}

Proses reservasi tiket yang ada saat ini belum memberikan kenyamanan, keamanan dan pemesanan tiket yang telah ada pun belum menjangkau semua kalangan karena perangkat mobile yang digunakan harus berteknologi tinggi (mendukung aplikasi WAP dan mempunyai resolusi layar tinggi).

Untuk mendapatkan segala informasi mengenai kondisi real dilapangan dan harapan yang diinginkan oleh penumpang dalam proses pemesanan tiket.

Hal yang dilakukan yaitu dengan melakukan menyebarkan daftar pertanyaan/pernyataan (kuesioner), pertanyaan/pernyataan yang diajukan nantinya berisikan tentang fakta yang ada tentang permasalahan yang dijadikan dasar penelitian ini.

\section{Analisa Sistem}

Analisa sistem adalah tahap dimana analis mengidentifikasi masalah - masalah kebutuhan sistem dan pemakai, menyatakan secara spesifik sasaran - sasaran yang harus dicapai untuk memenuhi kebutuhan pemakai, alternative masalah, metode pemecahan masalah yang tepat merencanakan dan menerapkan rancangan sistemnya.

1. Analisa Prosedur 
Proses pemesanan tiket yang selama ini berjalan adalah penumpang datang langsung menuju pool atau agen bus, selain itu bagi pelanggan setia, biasanya bisa langsung menelpon pihak agen.

Sedangkan tidak setiap hari bus yang tersedia diberangkatkan ke kota tujuan karena ada bus yang harus perpal (tidak berangkat) karena berbagai hal, info ini tidak sampai kepada penumpang yang akan memesan tiket, sedianya para penumpang baru mendapat info bus yang perpal tersebut setelah datang ke pool atau agen

Selain informasi keberangkatan adapun informasi harga tiket juga jarang diketahui secara langsung oleh penumpang, harga tiket perjalanan bersifat fluktuatif mengikuti situasi dan kondisi tertentu, bagi penumpang yang tidak menelpon agen, penumpang baru mendapat informasi harga tiket setelah.sampai di agen atau pool bus. Gambar 3 menunjukan flowchart dari SOP pemesanan tiket secara manual.

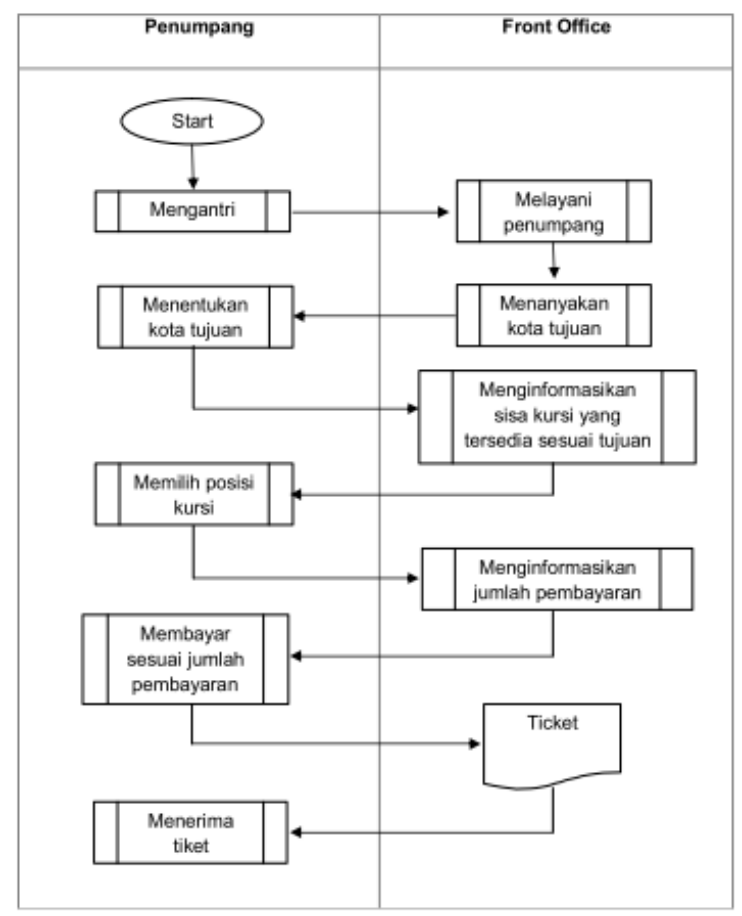

Gambar 3 Flowchart Diagram Pemesanan Tiket

2. Hasil Analisa Prosedur

Hasil analisa prosedur yang akan diterapkan nantinya dalam pemesanan tiket dengan menggunakan sms ini dapat ditunjukan dalam gambar 4 hasil analisa proses bisnis.

Gambar 4 menunjukan bahwa telah terjadinya beberapa alur proses pemesanan tiket yang sebelumnya telah berjalan secara manual, dengan demikian ditegaskan bahwa segala langkah yang berhubungan dengan system akan masuk dan direkam di dalam database. 


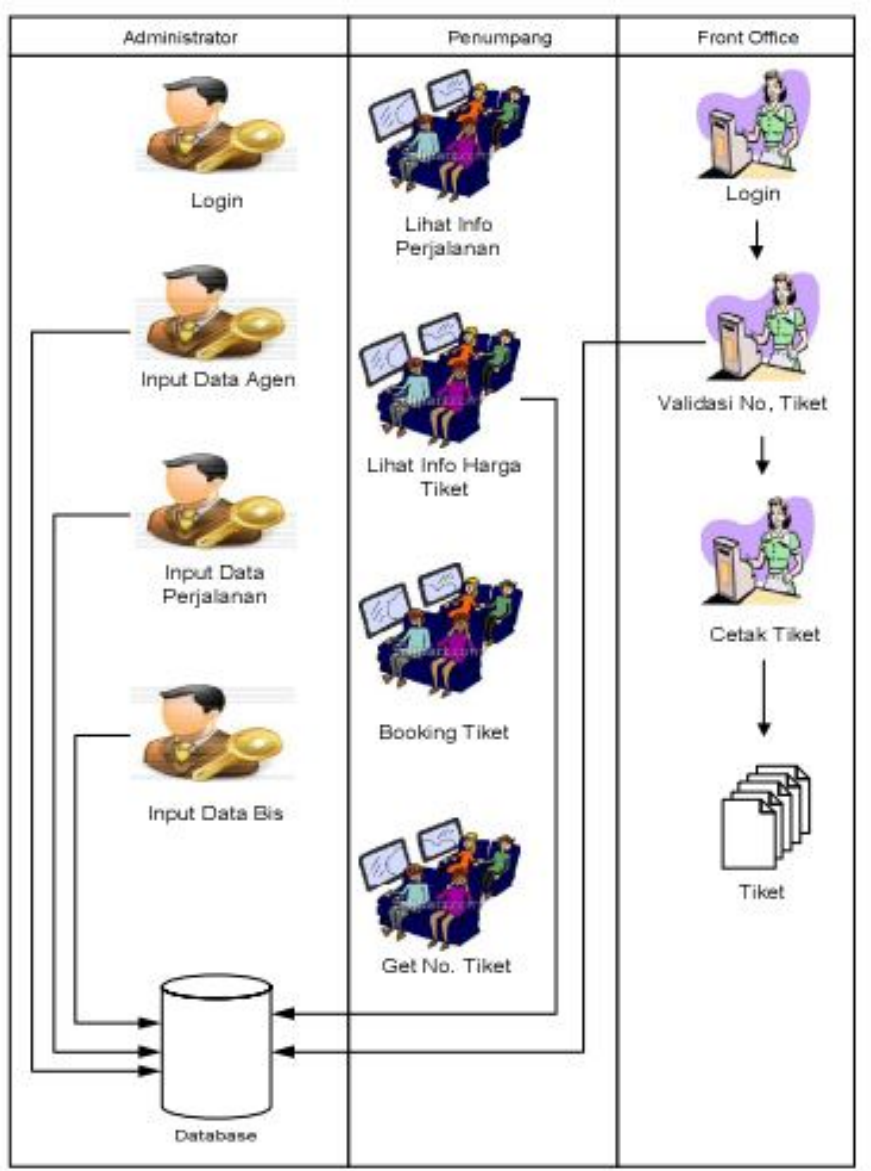

Gambar 4. Hasil Analisa Proses Bisnis

\section{Perancangan Sistem}

1. Diagram Konteks

Diagram konteks digunakan untuk menganalisis para pelaku dan mencari use case yang potensial. Adapun diagram konteks yang terjadi dalam penelitian ini dapat digambarkan sebagai berikut :

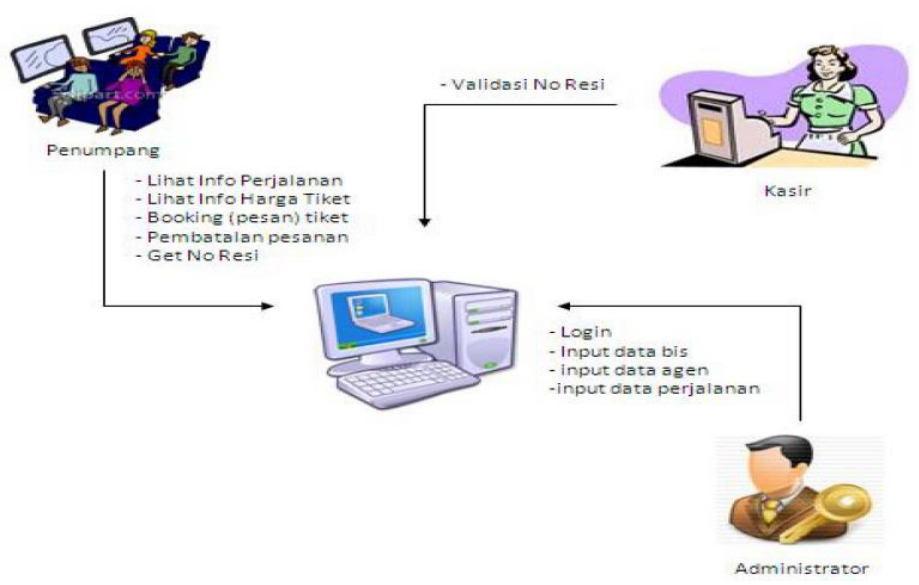

Gambar 5 Diagram Konteks 


\section{Usecase Diagram}

Usecase diagram adalah diagram yang menggambarkan intraksi antara sistem dengan sistem eksternal daan pengguna. Ada 2 elemen dasar dalam UML usecase diagram yaitu elips atau oval dan aktor. Elips berisi deskripsi dari interaksi aktor yang spesifik yang bekerja dengan sistem sesuai desain, terkadang ini digunakan untuk mempresentasikan hubungan antara sistem berikutnya. Aktor menggambarkan karakteristik interaksi orang atau sesuatu, berikut adalah usecase diagram dari sistem informasi pemesanan tiket

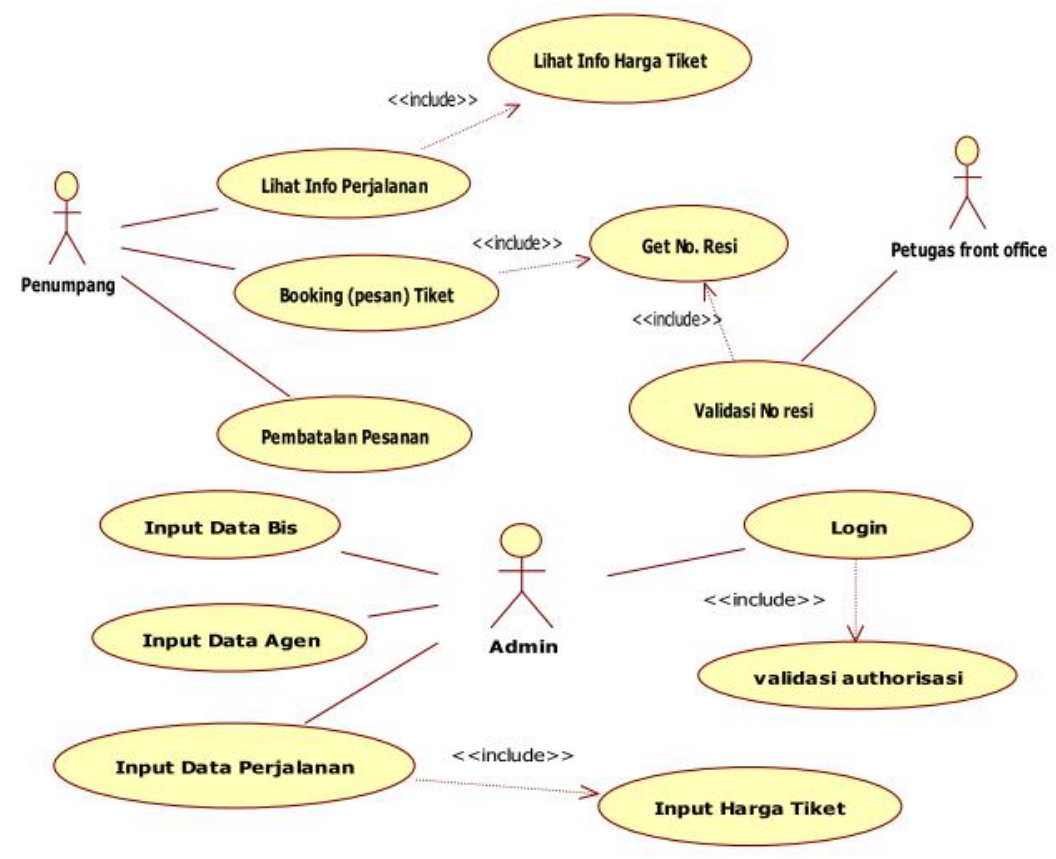

Gambar 6. Usecase Diagram

\section{Uji Coba Sistem}

Setelah perancangan dan sistem diimplementasikan, kemudian akan dilakukan tahap uji coba, uji coba dilakukan dua tahap, tahap yang pertama adalah uji coba lingkup internal dimana sistem akan diuji coba di lingkungan terbatas sebagai penguji adalah pengembang, uji coba kedua yaitu lingkup eksternal dimana sistem akan diuji di lingkup luar dan user (pembeli tiket dan stakeholder lainnya) sebagai penguji sistem.

\section{Uji Hipotesis}

Setelah sistem diimplementasikan dan diuji coba maka tahap selanjutnya adalah melakukan uji kelayakan dari sistem tersebut untuk mengukur sejauh mana sistem dapat digunakan.

Uji kelayakan ini dibuktikan dengan cara penyebaran kuisioner langsung ke end user yaitu penumpang sebagai pemakai sistem ini, penumpang diminta untuk mengisi kuisioner yang berisikan pertanyaan / pernyataan tentang kelayakan dan segala sesuatu dari sistem yang 
menunjukan kelayakan dari sistem ini, berikut adalah rekapitulasi dari perhitungan nilai kuisioner yang telah disebarka kepada end user.

Tabel 3. Rekapitulasi Penilaian Kuisioner

\begin{tabular}{|c|c|c|c|c|c|c|}
\hline No & Subjek & $x$ & $y$ & Xy & $x^{2}$ & $y^{2}$ \\
\hline 1 & mr.a & 38 & 26 & 988 & 1444 & 676 \\
\hline 2 & mr.b & 36 & 23 & 828 & 1296 & 529 \\
\hline 3 & mr.c & 49 & 28 & 1372 & 2401 & 784 \\
\hline 4 & mr.d & 33 & 18 & 594 & 1089 & 324 \\
\hline 5 & mr.e & 37 & 24 & 888 & 1369 & 576 \\
\hline 6 & mr.f & 38 & 23 & 874 & 1444 & 529 \\
\hline 7 & mr.g & 42 & 24 & 1008 & 1764 & 576 \\
\hline 8 & $\mathrm{mr} \cdot \mathrm{h}$ & 36 & 24 & 864 & 1296 & 576 \\
\hline 9 & $\mathrm{mr} . \mathrm{i}$ & 41 & 25 & 1025 & 1681 & 625 \\
\hline 10 & $m r . j$ & 33 & 20 & 660 & 1089 & 400 \\
\hline 11 & mr.k & 30 & 22 & 660 & 900 & 484 \\
\hline 12 & mr.l & 33 & 20 & 660 & 1089 & 400 \\
\hline 13 & $\mathrm{mr} . \mathrm{m}$ & 33 & 20 & 660 & 1089 & 400 \\
\hline 14 & $\mathrm{mr} . \mathrm{n}$ & 34 & 24 & 816 & 1156 & 576 \\
\hline 15 & mr.o & 33 & 20 & 660 & 1089 & 400 \\
\hline 16 & mr.p & 33 & 16 & 528 & 1089 & 256 \\
\hline \multirow{2}{*}{\multicolumn{2}{|c|}{$16=\mathrm{N}$}} & 579 & 357 & 13085 & 21285 & 8111 \\
\hline & & $\Sigma x$ & $\Sigma \mathrm{y}$ & $\Sigma x y$ & $\sum \mathrm{x}^{2}$ & $\Sigma y^{2}$ \\
\hline
\end{tabular}

Dari hasil rekapitulasi diatas dapat diidentifikasikan bahwa $x$ mewakili dari nilai variabel untuk mengukur trend dari sistem, dimana atribut yang dinilai adalah efektifitas, keamanan, kualitas, waktu, dan efisiensi dari sistem, sedangkan y merupakan nilai variabel untuk mengetahui layanan sistem, dimana atribut yang dinilai adalah Tangibles (wujud), Reliability (keandalan), Emphaty (empati).

Dari kedua variable diatas nilai $x$ dan $y$ dihitung dengan menggunakan rumus perhitungan product moment untuk mengetahui korelasi antara nilai $x$ dan nilai $y$, rumus dari product moment dapat dilihat dalam bab 3 pada bagian metode analisa data.

Hasil perhitungan berdasarkan rumus product moment aebagai berikut :

$$
\begin{aligned}
& R x y=\frac{((16)(13085))-(579)(357)}{\sqrt{\left[(16)(21285)-(579)^{2}\right]\left[(16)(8111)-(357)^{2}\right]}} \\
& R x y=\frac{209360-206703}{\sqrt{[340560-335241][129776-127449]}} \\
& R x y=\frac{2657}{\sqrt{[5319][2327]}} \\
& R x y=\frac{2657}{\sqrt{12377313}} \\
& R x y=\frac{2657}{3518.14} \\
& R x y=0.7552
\end{aligned}
$$


Dapat ditarik kesimpulan dari perhitungan diatas antara varibel $x$ dan y mempunyai nilai 0.7552 jika dilihat dari tabel konservatif diatas maka keterhubungan antara varibel $x$ yang mewakili penilaian trend dari sistem dan variabel y yang mewakili penilaian layanan sistem mempunyai nilai korelasi kuat.

\section{Kesimpulan}

Sistem infromasi pemesanan tiket bus antar kota antar propinsi ini merupakan sebuah aplikasi pemesanan tiket dengan menggunakan short message service (SMS) sebagai media pemesanan tiket.

Dalam penelitian ini peneliti ingin mengetahui apakah sistem ini dapat diterima oleh penumpang juga ingin mengetahui apakah sistem ini dapat menyelesaikan permasalahan yang terjadi pada proses pemesanan tiket secara manual, selain itu peneliti juga ingin mengetahui apakah sistem ini akan menjadi trend pemesanan tiket berbasis teknologi dimasa mendatang.

Dari berbagai permasalahan serta latar belakang penelitian ini, peneliti merumuskan kriteria - kriteria yang dianggap bisa menjawab pertanyaan dari tujuan penelitian ini maka dibuatkan variable penelitian.

Hasil dari perhitungan pada bab IV (Uji Kelayakan Sistem) maka jika dikonservatifkan dengan table konservatif produk moment (table konservatif dapat dilihat pada bab III) maka nilai 0.7552 mempunyai nilai korelasi kuat atau tinggi.

Dengan demikian menunjukan bahwa sistem informasi pemesanan tiket bus antar kota antar propinsi dengan menggunakan sms, dapat menjawab dari maksud penelitian ini yaitu terwujudnya rancangan sistem pemesanan tiket menggunakan teknik sms gateway. dan mencoba memberikan solusi alternatif untuk berbagai permasalahan yang muncul dalam penjualan tiket yang dilakukan secara manual, baik itu masalah teknis seperti penumpukan antrian maupun non teknis seperti pemalsuan tiket, dan menjawab dari tujuan penelitian ini yaitu dapat mengurangi permasalahan dari proses reservasi tiket secara manual, sistem reservasi tiket ini dapat dijangkau oleh semua kalangan dan menjawab bahwa sistem ini dapat menjadi trend dikemudian kelak.

\section{Saran}

Untuk pengembangan selanjutnya yang mangangkat tema yang sama, dapat disarankan untuk menutupi kekurangan yang ada dalam penelitian ini, berikut adalah saran yang dianjurkan :

1. Dalam proses pembayaran diharpakan bisa menggunakan teknologi mobile (mobile banking), sehingga pembayaran dapat langsung dari handphone pengguna.

2. Proses pembatalan pesanan juga bisa dilakukan langsung dari handphone pengguna. 


\section{Daftar Pustaka}

Guritno, Suryo, dkk. 2011. Theory and Application of IT Research, Penerbit Andi. Yogyakarta.

Herdiansyah, Haris. 2010. Metodologi Penelitian Kualitatif. Salemba Humanika, Jakarta. http://kntia.unsri.ac.id/documents/ANALISIS\%20KUALITAS\%20LAYANAN\%20SISTEM\%20INF ORMASI\%20MENGGUNAKAN\%20METODE\%20SERVQUAL.pdf

http://m.tribunjabar.co.id/read/artikel/38084/Tiket-Ganda-di-KA-Cireks-Beredar

http://pariwisata-teknologi.blogspot.com/2010/06/pengertian-reservasi.html

http://willis.comze.com/pengertian si.html

http://www.antaranews.com/berita/1279093421/pengguna-ponsel-indonesia-akan-capai-80-

persen

http://www.docstoc.com/?doc id=63443067\&download=1

Jogiyanto, HM. Akt., Mba., Ph.d. 2008. Metodologi Penelitian Sistem Informasi. Andi Yogyakarta.

Kadir, Abdul, 2003, Pengenalan Sistem Informasi, Andi Publisher, Yogyakarta

Kienan, Brenda. 2000. Small Bussiness Solution e-commerce. Elex Media Komputindo. Jakarta.

Maulana, Rizki. 2009. Mobile Ticketing Menggunakan Barcode Datamatrix Sebagai Aplikasi Pendukung Mobile Commerce. IT Telkom. Bandung.

McLeod Raymond, Jr. dkk, 2004, Sistem Informasi Manajemen, edisi 8, .PT. Indeks, Jakarta.

Nugroho, Adi. 2005. Analisis dan Perancangan Sistem Informasi Dengan Metodologi Berorentasi Objek, Penerbit Informatika. Bandung.

Purnomo, Adi. 2007. Pemrograman Java 2 Membangun Beragam Aplikasi Layanan SMS. Salemba Infotek. Jakarta.

Rangga, Rafidianto. 2007. Mobile Ticketing Untuk Reservasi Kereta Api. IT. Telkom. Bandung.

Simarmata, Janner. 2006. Aplikasi Mobile Commerce, Andi Publisher,Yogyakarta.

Sudijono, Anas. 2008, Pengantar Statistik Pendidikan. Pt. Raja Grafindo Persada. Jakarta.

Whitten L Jeffery dkk, 2004. Metode Desain dan Analisis Sistem, edisi 6, Andi Publisher Yogyakarta. 